
\title{
$\begin{array}{ll}\text { Research Square } & \begin{array}{l}\text { Preprints are preliminary reports that have not undergone peer review. } \\ \text { They should not be considered conclusive, used to inform clinical practice, } \\ \text { or referenced by the media as validated information. }\end{array}\end{array}$
}

\section{Ferns and Licophytes in Coal Mining Waste and Tailing Landfills}

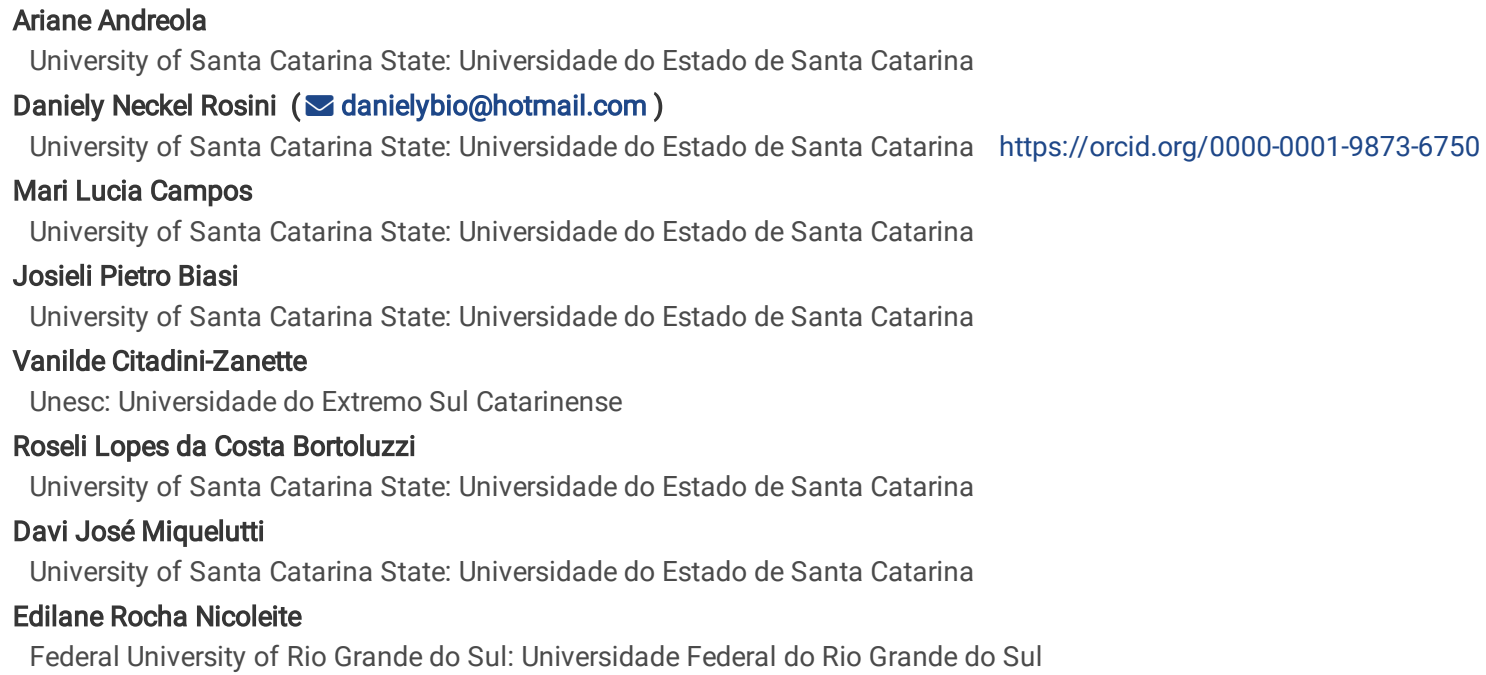

\section{Research Article}

Keywords: mining, trace elements, pteridophytes, environmental recovery

Posted Date: April 8th, 2021

DOI: https://doi.org/10.21203/rs.3.rs-232497/v1

License: (c) (i) This work is licensed under a Creative Commons Attribution 4.0 International License. Read Full License 


\section{Abstract}

Mineral coal extraction in Santa Catarina State (Brazil) Carboniferous Basin has degraded the local ecosystem, restricting the use of its areas. One of the biggest environmental impacts in the mining areas is the uncontrolled disposal of waste and sterile mining with high concentrations of pyrite, which in the presence of air and water is oxidized promoting the formation of acid mine drainage (AMD). These contaminants can be leached into water resources, restrict the use of water, soil and cause threats to fauna and flora. This study aimed to characterize these areas as to the content of $\mathrm{Cd}, \mathrm{Pb}, \mathrm{Ni}$ and $\mathrm{Zn}$ metals in the tailings and waste resulting from coal mining and to survey the species of ferns and lycophytes present. Wastes and tailing samples and specimens of ferns and lycophytes were collected in 23 landfills in six municipalities in the region and in four underlying areas used as controls. Chemical and physical analyses ( $\mathrm{pH}$ in water and $\mathrm{pH}$ in $\mathrm{KCl}, \mathrm{Ca}, \mathrm{Mg}, \mathrm{P}, \mathrm{K}, \mathrm{Na}, \mathrm{Mn}, \mathrm{Fe}, \mathrm{Al}$, clay and $\mathrm{OM}$ contents) were carried out and the total contents of heavy metals Cd, $\mathrm{Pb}$ were determined, $\mathrm{Ni}$ and $\mathrm{Zn}$. Sampling of ferns and lycophytes was carried out by walking. The levels of heavy metals, Cd, Ni and Zn were below the prevention concentrations established by CONAMA Resolution 420/2009. Pb levels were above prevention values in four landfills. Sixteen species of ferns and one lycophyte were found, with hemicryptophytes the most frequent and helophytes the most adapted to the environment. Of the species found, Pteridium esculentum (G. Forst.) Cockayne, Pityrogramma calomelanos (L.) Link and Telmatoblechnum serrulatum (Rich.) Perrie, DJ Ohlsen \& Brownsey demonstrated resistance to degraded and contaminated environments with $\mathrm{Pb}$, which may constitute an alternative for projects monitoring and environmental recovery.

\section{Intruduction}

Coal mining activity brought economic and social development to the southern region of Santa Catarina State, allowing the emergence of other sectors such as the ceramic, plastic and chemical industry. However, the activities of extraction, processing, transportation and storage of tailings and mining waste, over the years, have resulted in the contamination of natural resources and deforestation (Souza Junior et al. 2018).

For each ton of coal mined, about $60 \%$ of solid waste (tailings and waste) is generated (Campos et al. 2010). The term tailing means tailing pyrite, mine tailings and coal waste. These materials rich in iron sulphide (pyrite - $\mathrm{FeS}_{2}$ ), when in contact with water and atmospheric air, undergo oxidation reactions forming acidic chemical compounds, susceptible to leaching, responsible for the acid mine drainage (AMD) process, the main environmental impact in mined areas (Bilibio et al. 2020).

$\mathrm{AMD}$ is characterized by low $\mathrm{pH}(\leq 3)$, presence of $\mathrm{Al}, \mathrm{Fe}, \mathrm{Mn}$ and trace elements $\mathrm{As}, \mathrm{Cd}, \mathrm{Cu}, \mathrm{Ni}, \mathrm{Pb}, \mathrm{Zn}, \mathrm{Cr}$ and $\mathrm{Hg}$ in compositions and concentrations that depend on the kinetics of geochemical processes, mineralogy, type and quantity of oxidized sulphide, temperature, bacteria action, among other factors specific to each environment, which condition contamination levels, and can remain active for decades and even centuries after its production (Cunha et al. 2019; Yuan et al. 2019).

Although tailings and waste landfills are complex environments to support life, there are plant species capable of surviving in these places, such as some of pteridophytes, which are resistant to degraded environments, as they are undemanding in soil fertility, survive for long periods of drought and withstand environmental adversities well. These species cause the natural regeneration process to occur, once they begin colonization, creating conditions for other species to settle (Eslava-Silva et al. 2019; Marques and Krupek 2019; Praveen and Pandey 2020).

Due to the fact that they can survive in inhospitable places such as tailings landfills, have rusticity and are native species of the region, some pteridophytes can be a form of initial recovery of areas impacted by mining, seeking to re-establish ecological structures and functions that existed in the ecosystem before degradation (Prabhu et al. 2016). Pteridophytes include phytoremediation species capable of phyto volatizing, phyto stabilizing and phytoextracting heavy metals (Praveen and Pandey 2020).

The knowledge of the species of ferns and lycophytes capable of inhabiting the tailings and tailing landfills of mining is of importance, because in addition to the rusticity, some species are native to the region and can integrate projects of environmental recovery promoting the restructuring of the local ecosystem. In order to find viable alternatives for the restoration of ecosystems degraded by coal mining, this study presents a survey of pteridophytes that occur naturally in areas of tailings landfills in the Santa Catarina carboniferous basin and their relationship with high levels of heavy metals.

\section{Materials And Methods}

A study was carried out in 23 landfills and dumps of pyrite waste and in four areas without mining interference, in six municipalities belonging to the Santa Catarina state Carboniferous Basin, which occupies an area of $1,659 \mathrm{~km}^{2}$ (Milioli et al. 2009).

Sample points distribution on landfills was made according to the availability of entry into the areas, and in the cities of Criciúma and Urussanga, five landfills were according to the availability of entry into the areas, and in the cities of Criciúma and Urussanga, five landfills were collected each, in Lauro Muller and Siderópolis in four landfills each, in Treviso in three landfills and in Forquilhinha in two landfills. Areas without mining interference are located in Siderópolis (1) and Urussanga (3) (Figure 1). Details on the study areas are shown in Table 1.

Table 1 - Description of study areas where coal mining tailings landfills are located in southern Santa Catarina. 


\begin{tabular}{|c|c|c|c|c|}
\hline Municipality & Area & $\begin{array}{l}\text { Estimated } \\
\text { age } \\
\text { (years) }\end{array}$ & Area ID (*) & Description \\
\hline Urussanga & A1 & 32 & Setor Santana Ravine area 3 & $\begin{array}{l}\text { Two environments: ( } 1 \mathrm{st} \text { ) Landfill of coal fines and } \\
\text { ultrafines; ( } 2 \text { nd) landfill of waste. }\end{array}$ \\
\hline A2 & 32 & $\begin{array}{l}\text { Roadside } \\
\text { ravine }\end{array}$ & Tailings landfill & \\
\hline A3 & 32 & $\begin{array}{l}\text { Setor } \\
\text { Santana } \\
\text { Plano II } \\
\text { area } 4\end{array}$ & Fine and ultrafine coal Landfill & \\
\hline A4 & 32 & $\begin{array}{l}\text { Setor } \\
\text { Santana } \\
\text { Well } 8 \\
\text { area } 1\end{array}$ & Tailings landfill & \\
\hline A15 & 32 & $\begin{array}{l}\text { Open } \\
\text { area }\end{array}$ & $\begin{array}{l}\text { Open pit mining. Absence of topography and soil } \\
\text { construction practices. Presence of tailings and } \\
\text { waste. }\end{array}$ & \\
\hline AT2 & - & Control & Roadside ravine & \\
\hline AT3 & - & Control & Roadside ravine & \\
\hline AT4 & - & Control & Roadside ravine & \\
\hline Treviso & A6 & 52 & Open area & $\begin{array}{l}\text { Open pit mining. Two environments: (1st) Absence of } \\
\text { topography and soil construction practices. Tailing landfill. } \\
\text { (2nd) Landfill of fine and ultrafine coal. }\end{array}$ \\
\hline A20 & 52 & $\begin{array}{l}\text { Area } \\
\text { União }\end{array}$ & Tailings landfill & \\
\hline A21 & 52 & $\begin{array}{l}\text { Area } \\
\text { União }\end{array}$ & $\begin{array}{l}\text { Landfill of pyrite waste, mixture of soil and rock } \\
\text { fragments. }\end{array}$ & \\
\hline Siderópolis & A7 & 42 & Língua do Dragão & $\begin{array}{l}\text { Thin and ultrafine landfill. It currently receives effluents } \\
\text { from other ditches located around it. }\end{array}$ \\
\hline A19 & 42 & $\begin{array}{l}\text { Open } \\
\text { area }\end{array}$ & $\begin{array}{l}\text { Open pit mining. Absence of topography and soil } \\
\text { construction practices. Presence of tailings. }\end{array}$ & \\
\hline A22 & 42 & $\begin{array}{l}\text { Mina do } \\
\text { Trevo }\end{array}$ & $\begin{array}{l}\text { Open pit mining with the presence of a small layer of } \\
\text { "soil" on the surface covering tailings-pyrite. }\end{array}$ & \\
\hline A23 & 42 & $\begin{array}{l}\text { Mina do } \\
\text { Trevo }\end{array}$ & $\begin{array}{l}\text { Open pit mining with the presence of a small layer of } \\
\text { "soil" on the surface covering tailings - pyrite. }\end{array}$ & \\
\hline AT1 & - & Control & Roadside ravine & \\
\hline Criciúma & A8 & 42 & Bairro Colonial & Tailings landfill \\
\hline A9 & 42 & $\begin{array}{l}\text { Bairro } \\
\text { Santa } \\
\text { Luzia }\end{array}$ & Tailings landfill. Urban solid waste deposition. & \\
\hline A16 & 42 & $\begin{array}{l}\text { Setor } \\
\text { Linha } \\
\text { Batista }\end{array}$ & $\begin{array}{l}\text { Two environments: ( } 1 \mathrm{st}) \text { Landfill of waste. }(2 \mathrm{nd}) \\
\text { Landfill of fine and ultrafine coal. Occurrence of solid } \\
\text { urban waste. }\end{array}$ & \\
\hline A17 & 42 & $\begin{array}{l}\text { Setor } \\
\text { Linha } \\
\text { Batista }\end{array}$ & $\begin{array}{l}\text { Two environments: ( } 1 \mathrm{st}) \text { Landfill of waste. (2nd) } \\
\text { Landfill of fine and ultrafine coal. Occurrence of solid } \\
\text { urban waste. }\end{array}$ & \\
\hline A18 & 42 & $\begin{array}{l}\text { Setor } \\
\text { Linha } \\
\text { Batista }\end{array}$ & $\begin{array}{l}\text { Tailings landfill. Presence of AMD, rock fragment and } \\
\text { pyrite; intermittent lake formed by the contribution of } \\
\text { precipitation with bluish water. }\end{array}$ & \\
\hline Forquilhinha & A10 & 52 & Landfill & Deposition of fine and ultrafine coal. \\
\hline A11 & 52 & Landfill & $\begin{array}{l}\text { Decanting basin of fine and ultrafine coal with the } \\
\text { presence of small ponds with reddish water and } \\
\text { occurrence of AMD on de banks. }\end{array}$ & \\
\hline Lauro Muller & A5 & 40 & Rocinha & Pyrite waste landfill \\
\hline A12 & 40 & Area 10 & Tailings landfill & \\
\hline A13 & 40 & Area 4 & Tailings landfill & \\
\hline A14 & 40 & $\begin{array}{l}\text { Open } \\
\text { area }\end{array}$ & Tailings landfill & \\
\hline
\end{tabular}


*Areas identification according to the Federal Public Ministry of Santa Catarina official nomenclature.

Geology of the region falls within the Guatá Group, which includes non-glacial sediments and layers of coal, constituting the Rio Bonito (lower) and Palermo (upper) formations. The mineralogical constitution of Santa Catarina coal has quartz, kaolinite, plaster, muscovite, K-feldspar, as well as ferrous (sulphides), iron oxides and Al hydroxide silicates (Flores 2018). The representative soils of the region are Ultisols (43.1\%) and Inceptisols (24.2\%) (Milioli et al. 2009).

\subsection{Sample collection and evaluation methods}

The collections of fern and lycophyte specimens, pyritic waste and soil surrounding each plant were carried out using the walking method suggested by Filgueiras et al. (1994).

All plants were carefully removed completely and packaged, preserving the characteristics of each individual, as well as the pyrites and the soil. Samples of specimens and tailings were taken to the UDESC/CAV Environmental Survey and Analysis Laboratory for processing. Plants received identification, by delimiting families, following the classification proposed by Pteridophyta Philogeny Group (PPG I 2016), with genera and species being updated their scientific names by Flora do Brasil under construction (2020). For most species, the most relevant synonym was placed in the table with the floristic list, due to the fact that ancient scientific names are still found in some consulted bibliographies. Collected plants were desiccated, catalogued and incorporated into the collections of the LUSC Herbarium of the State University of Santa Catarina (UDESC/CAV) and the CRI Herbarium of the University of the Far South of Santa Catarina (UNESC).

The pyritic waste and the soil were dried in an oven for $24 \mathrm{~h}$ at $60^{\circ} \mathrm{C}$, being ground and passed through a $2 \mathrm{~mm}$ sieve. To characterize the tailings and soil, $\mathrm{pH}$ in water was determined using a soil/solution ratio of $1: 1$, contents of $\mathrm{P}, \mathrm{K}$ and $\mathrm{Na}$ by the Mehlich method; $\mathrm{Ca}, \mathrm{Mg}$ and $\mathrm{Al}$ with $\mathrm{KCl}^{1}$ mol L-1 solution (Tedesco et al. 1995) and organic matter (Walkley and Black 1934). Quantification of the Ca and $\mathrm{Mg}$ content was performed in an atomic absorption spectrometer, $\mathrm{P}$ and $\mathrm{MO}$ in UV-visible, and $\mathrm{K}$ by flame photometry. The determination of clay contents was based on the methodology proposed by Day (1965) and Gee and Bauder (1986). The pH values in KCl were also determined (EMBRAPA 1997).

Subsequently, in the tailings and soil samples, the total contents of $\mathrm{Cd}, \mathrm{Pb}, \mathrm{Ni}$ and $\mathrm{Zn}$ were determined, following the USEPA protocol, method 3051 (USEPA 2007). All analyses were performed in duplicates. The reliability of the analytical method was assessed using reference soil samples certified by the National Institute of Standards and Technology (NIST). For the analyses in question, the soil sample SRM 2709 A (San Joaquin) was used as reference. The Qualitative detection limit (QDL) was also determined (Table 2).

The quantification of the total contents of $\mathrm{Pb}, \mathrm{Ni}$ and $\mathrm{Zn}$ took place by means of the atomic absorption spectrometer, with atomization in CONTRAA 700 $\AA$ airacetylene flame (ANALYTIK JENA) and the total contents of $\mathrm{Cd}$ by the same equipment, however with electrothermal atomization, using as a chemical modifier the use of $1 \mathrm{~g}$ of $\mathrm{NH}_{4} \mathrm{H}_{2} \mathrm{PO}_{4}$ in $0.5 \mathrm{~mol} \mathrm{~L}^{-1} \mathrm{HNO}_{3}$ (Rucandio and Petit 1999)

Table 2 - Certified and recovered values of the trace elements of the reference sample NIST SEM 2709 A (San Joaquin) and Limit of operational detection and quantification, QDL respectively.

\begin{tabular}{|llll|}
\hline Element & NIST SEM 2709 certified & $\begin{array}{l}\text { \% NIST recuperation } \\
\mathrm{mg} \mathrm{kg}^{-1}\end{array}$ & $\begin{array}{l}\text { QDL } \\
\mathrm{mg} \mathrm{L}^{-1}\end{array}$ \\
\hline $\mathrm{Cd}$ & $0.31 \pm 0.002$ & 109.90 & 0.2113 \\
$\mathrm{~Pb}$ & $29 \pm 0.1$ & 95.37 & 0.0718 \\
$\mathrm{Ni}$ & $85 \pm 2$ & 79.45 & 0.0377 \\
$\mathrm{Zn}$ & $103 \pm 4$ & 85.90 & 0.0093 \\
\hline
\end{tabular}

\subsection{Statistical analysis}

Statistical analysis was conducted in three phases. Initially, data were submitted to descriptive analysis, aiming to characterize the frequency distributions of the variables and to identify outliers. Next, a univariate analysis of variance was performed for the effect of the area factor on the variables $\mathrm{Cd}$, $\mathrm{Pb}$, Ni and $\mathrm{Zn}$ followed by the Scott-Knott test, when relevant. The grouping analysis of the areas was also carried out according to the presence or absence of the observed species. In the tests, the minimum significance level of $5 \%$ was adopted. The determination of the multivariate distance between the areas was performed based on the presence or absence of pteridophyte species from the Jaccard index calculation. Ward's hierarchical method was adopted as an agglomeration algorithm (R Core Team 2019).

\section{Result And Discussion}

\section{Chemical, physical and heavy metal characterization of waste and tailing}

Tailings and waste resulting from coal mining have low values of $\mathrm{pH}$, clay and sum of bases as well as low levels of $\mathrm{Ca}, \mathrm{Mg}, \mathrm{K}, \mathrm{Na}$ and $\mathrm{Mn}$ and high levels of $\mathrm{P}, \mathrm{Al}$, exchangeable Fe and organic matter. Of the 23 landfills evaluated, only A23 has different chemical properties, with high values of pH, Ca, Mg, SB, P, Mn 
and organic matter and low Al levels when compared to the other landfills (Table 3). The low pH values are due to the presence of sulphidized minerals such as pyrite $\left(\mathrm{FeS}_{2}\right)$, contained in the tailings and tailing landfills, which oxidize giving rise to AMD, producing sulfuric acid and causing the $\mathrm{pH}$ to fall (Staub 2019).

Table 3 - Characterization of waste pyrite and tailing from coal mining in the 23 landfills and soil in the 04 areas without mining interference, in the Santa Catarina Carboniferous Basin. Values average $\left(^{*}\right)$.

\begin{tabular}{|c|c|c|c|c|c|c|c|c|c|c|c|}
\hline LF & pH water & $\mathrm{pH} \mathrm{KCl}$ & $\mathrm{Ca}$ & $\mathrm{Mg}$ & $\mathrm{K}$ & $\mathrm{Na}$ & SB & Al & $P$ & M.O & Ar. \\
\hline $\mathrm{Cmolc} \mathrm{kg}^{-1}$ & $\mathrm{mg} \mathrm{kg}^{-1}$ & $\mathrm{~g} \mathrm{~kg}^{-1}$ & & & & & & & & & \\
\hline $\mathrm{A} 1$ & 2.8 & 2.8 & 3.2 & 0.1 & 1.0 & 0.1 & 4.5 & 7.3 & 3.3 & 56 & 180 \\
\hline $\mathrm{A} 2$ & 3.2 & 2.6 & 3.7 & 0.2 & 0.2 & 0.1 & 4.2 & 4.6 & 1.5 & 54 & 190 \\
\hline A3 & 3.0 & 2.7 & 6.3 & 0.1 & 0.1 & 0.1 & 6.7 & 7.3 & 2.1 & 46 & 140 \\
\hline A4 & 2.6 & 2.1 & 4.4 & 0.1 & 0.1 & 0.1 & 4.6 & 5.8 & 1.2 & 36 & 150 \\
\hline A5 & 2.7 & 2.5 & 5.7 & 0.1 & 0.1 & 0.1 & 6.0 & 7.0 & 3.2 & 56 & 150 \\
\hline A6 & 2.6 & 2.7 & 4.0 & 0.1 & 0.1 & 0.2 & 4.3 & 7.9 & 2.1 & 40 & 180 \\
\hline A7 & 2.5 & 2.4 & 3.6 & 0.1 & 0.1 & 0.1 & 3.9 & 5.2 & 2.7 & 93 & 190 \\
\hline A8 & 3.2 & 3.0 & 4.7 & 0.1 & 0.1 & 0.2 & 5.0 & 5.3 & 1.5 & 37 & 340 \\
\hline A9 & 2.2 & 2.4 & 3.2 & 0.1 & 0.1 & 0.1 & 3.5 & 9.7 & 2.5 & 93 & 400 \\
\hline A10 & 2.8 & 2.9 & 6.3 & 0.3 & 0.4 & 0.3 & 7.3 & 9.1 & 21.4 & 61 & 240 \\
\hline A11 & 3.0 & 2.8 & 4.9 & 0.1 & 0.1 & 0.2 & 5.3 & 8.0 & 1.9 & 24 & 240 \\
\hline A12 & 3.0 & 2.8 & 3.7 & 0.2 & 0.1 & 0.1 & 4.1 & 9.5 & 2.7 & 30 & 180 \\
\hline A13 & 3.3 & 2.8 & 2.7 & 0.1 & 0.2 & 0.1 & 3.1 & 7.6 & 1.6 & 39 & 240 \\
\hline A14 & 3.1 & 2.7 & 4.0 & 0.1 & 0.1 & 0.2 & 4.5 & 4.9 & 10.0 & 31 & 225 \\
\hline A15 & 3.0 & 2.9 & 2.4 & 0.1 & 0.1 & 0.2 & 2.7 & 6.4 & 8.0 & 18 & 220 \\
\hline A16 & 2.8 & 2.9 & 5.3 & 0.1 & 0.1 & 0.2 & 5.7 & 10.2 & 2.6 & 24 & 220 \\
\hline A17 & 3.4 & 3.2 & 3.5 & 0.1 & 0.3 & 0.2 & 4.3 & 7.7 & 23.8 & 18 & 270 \\
\hline A18 & 3.1 & 3.0 & 3.5 & 0.1 & 0.2 & 0.1 & 4.0 & 6.7 & 1.45 & 29 & 190 \\
\hline A19 & 3.2 & 2.9 & 3.3 & 0.1 & 0.2 & 0.1 & 3.7 & 7.8 & 1.0 & 36 & 240 \\
\hline A20 & 3.3 & 3.3 & 3.8 & 0.1 & 0.2 & 0.2 & 4.3 & 11.3 & 2.3 & 15 & 300 \\
\hline A21 & 3.0 & 2.7 & 3.9 & 0.1 & 0.2 & 0.2 & 4.5 & 6.9 & 6.3 & 18 & 200 \\
\hline A22 & 2.8 & 2.7 & 3.1 & 0.1 & 0.1 & 0.2 & 3.2 & 4.1 & 12.4 & 26 & 220 \\
\hline A23 & 5.3 & 5.5 & 33.4 & 3.0 & 0.1 & 0.2 & 36.8 & 1.9 & 81.9 & 44 & 220 \\
\hline AT1 & 4.2 & 5.8 & 6.9 & 0.1 & 0.3 & 0.3 & 7.6 & 4.1 & 3.6 & 21 & 380 \\
\hline AT2 & 4.3 & 3.9 & 4.5 & 0.1 & 0.2 & 0.2 & 5.0 & 1.5 & 2.3 & 18 & 190 \\
\hline AT3 & 4.0 & 3.5 & 4.3 & 0.1 & 0.3 & 0.2 & 4.9 & 7.2 & 3.2 & 17 & 290 \\
\hline AT4 & 4.1 & 3.6 & 4.5 & 0.1 & 0.2 & 0.2 & 5.0 & 4.0 & 3.3 & 16 & 220 \\
\hline
\end{tabular}

${ }^{*}$ ) LF: Landfill; A: Landfill area; AT: area without mining interference. Med: Average; Min.: Minimum; Max.: Maximum.

Low levels of $\mathrm{Ca}, \mathrm{Mg}, \mathrm{K}, \mathrm{Na}$ and $\mathrm{Mn}$ that result in low base sum values, denote the loss of the elements by leaching. This occurs due to the weathering of the minerals contained in the tailings, caused by AMD, which releases substantial loads of $\mathrm{SO}_{4}{ }^{2-}$, which can be associated with the elements and result in the loss by leaching (Kefeni et al. 2017). High levels of $P$, can be attributed to the formation of iron and aluminium oxides and hydroxides by the acid drainage process, leading to the specific adsorption of the element (Boukemara et al., 2017).

High levels of exchangeable Fe and Al are due to the presence of iron and aluminium minerals in the tailings and to the AMD process that increases the soluble forms of these elements. The free forms of Fe and Al occur only in extremely acidic conditions $(\mathrm{pH}<1)$, whereas complexation with metals is dominant at $\mathrm{pH}$ ranging between $1.0-4.5$ for Fe and $1.5-6,0$ for $\mathrm{Al}$ (Nordstrom 2020).

Organic matter content is considered high, compared to the control areas, which can be caused by the type and origin of Santa Catarina coal and the method of determination used. Santa Catarina coal is of the sub-bituminous coal type originated from plant material, containing high amounts of organic carbon (80 
to $85 \%$ ) in its composition, due to the carbonification process. Estimating organic matter in mined areas is difficult due to the carbon contribution from the coal fragments and the Fe and Mn oxidation reduction processes (Somani et al. 2020).

The A23 landfill has different chemical properties, because, according to information from the National Department of Mineral Production (DNPM), it had already undergone a recovery process in 2005, in compliance with the Plan for the Recovery of Degraded Areas (PRAD). However, it was considered in this study because it still contains tailings mixed with the soil. The chemical properties related to the exchange complex, $\mathrm{Ca}, \mathrm{Mg}, \mathrm{Na}, \mathrm{K}$ and sum of bases (SB) have values higher than those found in other landfills and similar to areas without contamination. These results agree with those obtained by Inda et al. (2010) in soils built in SC, indicating a more active process of proton dissolution of buffering minerals, possibly present in the soil used in the recovery. The higher $\mathrm{pH}$ and $\mathrm{P}$ content indicate the correction of the soil built through liming and fertilization.

Control areas showed similar chemical properties, having low levels of basic cations (Ca, $\mathrm{Mg}, \mathrm{K}$ and $\mathrm{P}$ ), low pH values and high levels of exchangeable $\mathrm{Al}$ (Table 3), demonstrating that the soils in the region are chemically poor, with an halitic character, that is, with low base saturation and high with Al, high activity clay, exchangeable Al levels greater than $4 \mathrm{cmol}_{\mathrm{c}} \mathrm{kg}^{-1}$ (Campos et al. 2003).

Table 4 - Trace elements content in the tailings and waste from coal mining and in the soil of areas without contamination, in the Santa Catarina Carboniferous Basin $\left(^{*}\right)$.

\begin{tabular}{|c|c|c|c|c|}
\hline Landfill/Control & $\mathrm{Cd}$ & $\mathrm{Pb}$ & $\mathrm{Ni}$ & $\mathrm{Zn}$ \\
\hline $\mathrm{mg} \mathrm{Kg}^{-1}$ & & & & \\
\hline A1 & $0.6 \mathrm{a}$ & $59.3 c$ & $1.6 \mathrm{e}$ & $34.7 c$ \\
\hline $\mathrm{A} 2$ & $0.6 \mathrm{a}$ & $81.2 \mathrm{c}$ & $4.8 \mathrm{~d}$ & $41.1 \mathrm{c}$ \\
\hline A3 & $0.6 \mathrm{a}$ & $50.2 c$ & $4.3 d$ & $56.9 \mathrm{c}$ \\
\hline A4 & $0.6 \mathrm{a}$ & $43.2 \mathrm{c}$ & $3.0 \mathrm{~d}$ & $42.0 \mathrm{c}$ \\
\hline A5 & $0.6 \mathrm{a}$ & $58.4 \mathrm{c}$ & $2.6 e$ & $56.7 \mathrm{c}$ \\
\hline A6 & $<\mathrm{LDQ}$ & $51.6 c$ & $7.5 \mathrm{c}$ & $49.1 \mathrm{c}$ \\
\hline A7 & $0.8 \mathrm{a}$ & 349.1 a & $2.3 e$ & $54.5 \mathrm{c}$ \\
\hline A8 & $<\mathrm{LDQ}$ & $50.7 \mathrm{c}$ & $3.7 d$ & $50.0 \mathrm{c}$ \\
\hline A9 & $<\mathrm{LDQ}$ & $162.4 \mathrm{~b}$ & $2.4 \mathrm{e}$ & $42.6 \mathrm{c}$ \\
\hline A10 & $0.3 \mathrm{a}$ & $43.9 c$ & $12.8 \mathrm{~b}$ & $42.2 \mathrm{c}$ \\
\hline A11 & $0.3 \mathrm{a}$ & $61.8 \mathrm{c}$ & $21.3 \mathrm{a}$ & $71.0 \mathrm{~b}$ \\
\hline A12 & $0.6 \mathrm{a}$ & $31.0 \mathrm{c}$ & $5.1 c$ & $35.7 c$ \\
\hline A13 & $<\mathrm{LDQ}$ & $34.6 c$ & $8.4 c$ & $46.9 \mathrm{c}$ \\
\hline A14 & < LQO & $45.4 \mathrm{c}$ & $7.2 \mathrm{c}$ & $34.3 c$ \\
\hline A15 & $0.6 a$ & $64.4 \mathrm{c}$ & $4.9 \mathrm{c}$ & $35.7 \mathrm{c}$ \\
\hline A16 & $0.6 a$ & $58.2 \mathrm{c}$ & $2.1 \mathrm{e}$ & $84.2 \mathrm{~b}$ \\
\hline A17 & $0.6 \mathrm{a}$ & $29.8 c$ & $9.6 \mathrm{~b}$ & $43.1 \mathrm{c}$ \\
\hline A18 & $0.6 \mathrm{a}$ & $73.9 c$ & $7.2 \mathrm{c}$ & $178.0 \mathrm{a}$ \\
\hline A19 & $<\mathrm{LDQ}$ & $47.0 \mathrm{c}$ & $6.2 \mathrm{c}$ & $83.2 \mathrm{~b}$ \\
\hline A20 & $0.6 \mathrm{a}$ & 40.7c & $9.9 b$ & $57.0 \mathrm{c}$ \\
\hline A21 & $0.6 \mathrm{a}$ & $38.6 \mathrm{c}$ & $10.7 \mathrm{~b}$ & $35.7 \mathrm{c}$ \\
\hline A22 & $<\mathrm{LDQ}$ & $62.9 c$ & $3.4 \mathrm{~d}$ & $60.4 c$ \\
\hline A23 & $<\mathrm{LDQ}$ & $34.6 \mathrm{c}$ & $9.8 b$ & $88.7 b$ \\
\hline AT1 & $<\mathrm{LDQ}$ & $64.2 c$ & $5.4 c$ & $77.7 \mathrm{~b}$ \\
\hline AT2 & $<\mathrm{LDQ}$ & $48.2 \mathrm{c}$ & $2.5 \mathrm{e}$ & $68.5 b$ \\
\hline AT3 & $0.4 \mathrm{a}$ & $51.2 \mathrm{c}$ & $1.6 \mathrm{e}$ & $80.2 \mathrm{~b}$ \\
\hline AT4 & $<\mathrm{LDQ}$ & $68.9 c$ & $5.9 c$ & $50.4 \mathrm{c}$ \\
\hline
\end{tabular}

(*) Averages followed by the same letters in the vertical do not differ by the Scott-Knott test $(P>0,05) ; L D Q=0,2113$.

Total levels of trace elements $\mathrm{Cd}, \mathrm{Pb}, \mathrm{Ni}$ and $\mathrm{Zn}$ quantified in the tailings can be seen in Table 4. No differences were observed in total levels of Cd between the studied sites, with most of them being below the detection limit instrumental. The Ni content provided the greatest discrimination between the locations, 
separating them into five distinct classes, only six landfills presented values higher than the control areas. In the case of $\mathrm{Zn}$, three classes were formed, with only the A18 landfill (178 mg kg-1) having a higher concentration than the control areas. These two elements, together with the Cd, presented levels below the prevention values established by Resolution 420/2009 of Conama (30 mg kg-1,300 mg kg-1 and $1.3 \mathrm{mg} \mathrm{kg}^{-1}$, respectively) (Brazil 2009).

The $\mathrm{Pb}$ contents observed in landfills A7, A9, A2 and A18, were higher than the prevention value (72 $\left.\mathrm{mg} \mathrm{kg}^{-1}\right)$, established by CONAMA Resolution 420/2009 (Brazil 2009). The presence of these elements may be associated with metal sulphides that have a high affinity for trace elements, as well as pyrite that can naturally adsorb them on its surface (Tabelin et al. 2020). There is a direct influence of pyrite on the concentrations of all toxic elements of the tailings including sulphur, reporting it as an omnipresent component with environmental relevance, considering it as a reservoir of trace elements (Dutta et al., 2020).

Some other factors such as the geochemistry of heavy metals and the time of formation and exposure of landfills (Table 1) may be associated with the concentration of these elements. The concentration of heavy metals in the tailings and waste is also conditioned to the mineralogical composition of the coal that brings with it different metallic ions. Brazilian coal is characterized by a high range of sulphide minerals such as pyrite, marcasite and secondary minerals, formed from the AMD process, such as jarosite and schwertmannite, which can assimilate elements such as $\mathrm{Pb}, \mathrm{As}$ and $\mathrm{Cr}$ (Oliveira et al. 2019; Mireles et al. 2016). The oxidation of other iron sulphides, such as pyrrhotite (FeS), arsenopyrite (AsFeS) and chalcopyrite (CuFeS 2 ), can also generate acidic solutions and provide toxic elements. However, not all sulphide minerals present in mineral coal undergo acid hydrolysis, galena (PbS), sphalerite (ZnS) and chalcocite (CuS), for example, can release metals present in their structures without causing acidity which depends on the chemical balance of the medium (Benavente et al. 2020). Thus, the occurrence of $\mathrm{Cd}, \mathrm{Ni}, \mathrm{Zn}$ and $\mathrm{Pb}$, in the coal tailings, even in amounts considered low, is indicative of the dissolution of potentially contaminating minerals.

Under low $\mathrm{pH}$ conditions $\mathrm{Cd}, \mathrm{Ni}$ and $\mathrm{Zn}$ form electrostatic bonds with clay minerals and organic matter, with their exchangeable and soluble forms favoured which can cause losses by leaching (Duarte et al. 2019). Evaluating the leachate from the coal residue of SC, Silva et al. (2011) found Mn, Zn, Cu, Co and Ni as the main elements leached under low pH conditions, whereas $\mathrm{Cd}$ and $\mathrm{Zn}$ were found at higher levels than the average of the world's coals, occurring mainly in pyrite and alternatively in some clay minerals. According to the studies by Cutruneo et al. (2014), the oxidation of sulphides in coal waste from Santa Catarina, showed high concentrations of $\mathrm{Zn}, \mathrm{Cu}, \mathrm{Mn}, \mathrm{Co}, \mathrm{Ni}$ and $\mathrm{Cd}$ in the leachate, associated with acidic conditions and the oxidation of pyrite, these elements being lost in a short time.

The high levels of $\mathrm{Pb}$ occurring in landfills $\mathrm{A} 2, \mathrm{~A} 7, \mathrm{~A} 9$ and $\mathrm{A} 18$, may be associated with the geochemistry of the element, which is not very mobile and may be complexed by organic matter, chemosorbed in silicate oxides and minerals and precipitated as carbonate, hydroxides or phosphate, being one of the most abundant toxic metals in coal (Pelletier et al. 2020). Most of the $\mathrm{Pb}$ can be adsorbed by goethite. Its stability field in the $\mathrm{Pb}-\mathrm{S}-\mathrm{C}-\mathrm{O}-\mathrm{H}$ system is small, mainly at low $\mathrm{pH}$ values $(\mathrm{pH}<5)$ combined with oxidation conditions and high concentrations of sulphates in solution (Akopyan et al. 2018).

Lead can bioaccumulate in the food chain and is a metal that has no beneficial nutritional effects known to animals. Despite the low mobility, when it comes into contact with chelating agents, it can be solubilized in the soil and be absorbed in greater quantity by plants (Babaeian et al. 2015). In the human body, lead can cause neurotoxic, haematological, cardiovascular, gastrointestinal effects, kidney disorders, arterial hypertension and has evidence of carcinogenicity (Ruppenthal 2013; Grant 2020). Studies demonstrate a strong relationship between exposure to lead and cadmium and functional dependence in an elderly population (Chen et al. 2020; Hara et al. 2016; Musilova et al. 2016).

\subsection{Ferns and Lycophytes}

17 species were registered, distributed in 14 genera belonging to 11 botanical families of pteridophytes in the areas of tailings landfills and mining waste in the region of the Santa Catarina carboniferous basin (Table 5).

Table 5 - Species of ferns and lycophytes found in the tailings and waste landfills of mining in the region of the Santa Catarina carboniferous basin. 


\begin{tabular}{|c|c|c|c|c|}
\hline Family/Genus/Species/ Species code & $\begin{array}{l}\text { Preferred } \\
\text { environments } \\
\star\end{array}$ & $\begin{array}{l}\text { Biological } \\
\text { forms * }\end{array}$ & $\begin{array}{l}\text { Environmental } \\
\text { adaptations * }\end{array}$ & Place of collection (Landfills) \\
\hline \multicolumn{5}{|l|}{ LYCOPHYTS } \\
\hline \multicolumn{5}{|l|}{ LYCOPODIACEAE } \\
\hline $\begin{array}{l}\text { Palhinhæa cernua (L.) Franco \& Vasc. (sin. } \\
\text { Lycopodiumcernuum L.; Lycopodiellacernua (L.) Pic. } \\
\text { Serm.) (E1) }\end{array}$ & LU, LA & $\mathrm{C}$ & ME, HE & $\begin{array}{l}\text { A13, A14 (Lauro Muller), A15 (Urussanga), } \\
\text { A16, A17 (Criciúma), A19 (Siderópolis) }\end{array}$ \\
\hline \multicolumn{5}{|l|}{ FERNS } \\
\hline \multicolumn{5}{|l|}{ ANEMIACEAE } \\
\hline $\begin{array}{l}\text { Anemia phyllitidis (L.) Sw. (sin. Anemia candidoi Brade) } \\
\text { (E2) }\end{array}$ & IM, BM, BR & $\mathrm{H}$ & ES & A23 (Siderópolis) \\
\hline \multicolumn{5}{|l|}{ BLECHNACEAE } \\
\hline $\begin{array}{l}\text { Neoblechnum brasiliense } \\
\text { (Desv.) Gasper \& V.A.O. Dittrich (sin. Blechnum brasiliense } \\
\text { Desv.) (E3) }\end{array}$ & BM, IM, LA & $\mathrm{C}$ & ME, ES & $\begin{array}{l}\text { A2, AT3 (Urussanga), A17 (Criciúma), A19, } \\
\text { A22, A23, AT1 (Siderópolis) }\end{array}$ \\
\hline $\begin{array}{l}\text { Telmatoblechnum serrulatum (Rich.) Perrie, D.J. Oh/sen \& } \\
\text { Brownsey } \\
\text { (sin. Blechnum serrulatum Rich.) (E4) }\end{array}$ & BM, IM, LA & C & ME, ES & $\begin{array}{l}\text { A3 (Urussanga), A5 (Lauro Muller), } \\
\text { A7(Siderópolis), A8, A16 (Criciúma), A22 } \\
\text { (Siderópolis) }\end{array}$ \\
\hline \multicolumn{5}{|l|}{ CYATHEACEAE } \\
\hline $\begin{array}{l}\text { Cyathea atrovirens (Langsd. \& Fisch.) Domin (sin. } \\
\text { Alsophila atrovirens } \\
\text { (Langsd. \& Fisch.) C.Presl) (E5) }\end{array}$ & BM & $\mathrm{F}$ & $\mathrm{HE}$ & $\begin{array}{l}\text { A13, A14 (Lauro Muller), A17 (Criciúma), A19 } \\
\text { (Siderópolis) }\end{array}$ \\
\hline $\begin{array}{l}\text { Cyathea cf. phalerata Mart. (sin. } \\
\text { Alsophila phalerata } \\
\text { (Mart.) Mart.) (E6) }\end{array}$ & $\mathrm{IM}$ & $\mathrm{F}$ & $\mathrm{HE}$ & A19 (Siderópolis) \\
\hline
\end{tabular}

Tabela 5 - Species found in the tailings and waste landfills in the region of the Santa Catarina coal basin (continued). 


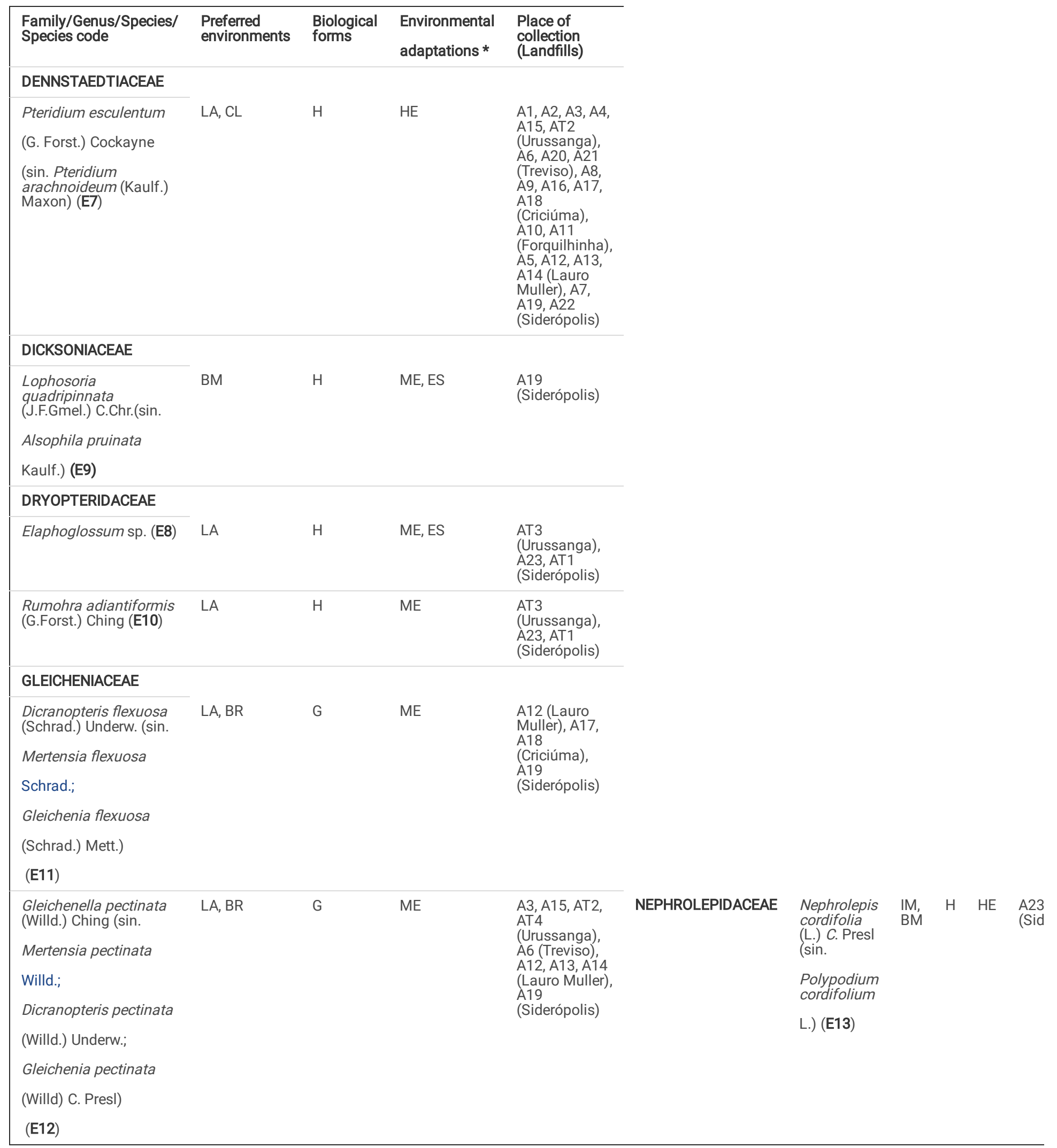

Tabela 5 - Species found in the tailings and waste landfills in the region of the Santa Catarina coal basin (continued). 


\begin{tabular}{|c|c|c|c|c|}
\hline $\begin{array}{l}\text { Family/Genus/Species/ Species } \\
\text { code }\end{array}$ & $\begin{array}{l}\text { Preferred } \\
\text { environments }\end{array}$ & $\begin{array}{l}\text { Biological } \\
\text { forms }\end{array}$ & $\begin{array}{l}\text { Environmental } \\
\text { adaptations * }\end{array}$ & Place of collection (Landfills) \\
\hline PTERIDACEAE & \multirow[b]{2}{*}{ CL, LU, LA } & \multirow[b]{2}{*}{$\mathrm{H}$} & \multirow[b]{2}{*}{$\mathrm{ME}, \mathrm{HE}$} & \multirow[b]{2}{*}{$\begin{array}{l}\text { A1, A2, A4, A15, AT2, AT4 (Urussanga), A5 (Lauro Muller), A6, A20, } \\
\text { A21 (Treviso), A8, A9, A16, A17, A18 (Criciúma), A10, A11 } \\
\text { (Forquilhinha), A12, A13, A14 (Lauro Muller), A7, A19, A22 } \\
\text { (Siderópolis) }\end{array}$} \\
\hline $\begin{array}{l}\text { Pityrogramma calomelanos (L.) } \\
\text { Link. (sin. } \\
\text { Gymnogramma calomelanos } \\
\text { L.) (E15) }\end{array}$ & & & & \\
\hline THELYPTERIDACEAE & \multirow[b]{2}{*}{ IM, BM } & \multirow[b]{2}{*}{$\mathrm{H}$} & \multirow[b]{2}{*}{ ES } & \multirow[b]{2}{*}{ A22, A23 (Siderópolis) } \\
\hline $\begin{array}{l}\text { Macrothelypteris torresiana } \\
\text { (Gaudich.) Ching (sin. } \\
\text { Polystichum torresianum } \\
\text { Gaudich.) (E16) }\end{array}$ & & & & \\
\hline $\begin{array}{l}\text { Christella dentata } \\
\text { (Forssk.) Brownsey \& Jermy (sin. } \\
\text { Thelypteris dentata (Forssk.) } \\
\text { E.P.St.John) (E17) }\end{array}$ & $\mathrm{IM}, \mathrm{BM}$ & $\mathrm{H}$ & HE & A23 (Siderópolis) \\
\hline
\end{tabular}

(*) - - CL - Clearing; BM - Forest edge; BR - Ravine; IM - Inside the forest; LU - Wet Location; LA - Open Site; C - Caméfita; H - Hemicryptophyte; G - Geophyte; F Phanerophyte; ME - Mesophyte; ES - Sciófita; HE - Heliophyte; HI - Hygrophyte; XE - Xerophyte.

Regarding the representativeness of the families, Dryopteridaceae showed the highest specific richness with three species, followed by Blechnaceae, Cyatheaceae, Gleicheniaceae and Thelypteridaceae with two species each and Anemiaceae, Dennstaedtiaceae, Dicksoniaceae, Lycopodiaceae and Pteridaceae with only one species each. Some families have certain striking characteristics, as in the case of Gleicheniaceae, Dennstaedtiaceae and Lycopodiaceae, in which their species were found exclusively in places that denote environments with direct incidence of sunlight and humidity, showing that such species develop in altered and sunny environments. The same behaviour was registered in work carried out in the Itajaí National Park, for these families (Gasper and Sevegnani 2010).

Regarding preferential environments, the predominant form was an open place comprising ten species, with greater representation in the genera Blechnum, Elaphoglossum, Pteridium, Rumohra, Dicranopteris, Gleichenella, Palhinhaea and Pityrogramma. In the interior and edge of the forest, the second largest representation was found, with eight genera, Anemia, Blechnum, Cyathea, Nephrolepis, Lophosoria, Macrothelypteris and Christella. The third preferred environment was a bank with four species of the genera Anemia, Dicranopteris, Gleichenella and Lygodium. Finally, the clearing and humid environment with only two species each, belonging to the genera Pteridium, Palhinhaea and Pityrogramma.

Regarding biological forms, hemicryptophytes are represented by ten species in Anemiaceae, Dennstaedtiaceae, Dicksoniaceae, Dryopteridaceae, Lygodiaceae, Pteridaceae and Thelypteridaceae, which is the predominant biological form. The camphite form is represented by three species of Blechnaceae and Lycopodiaceae, followed by the geophyte form with two species of the family Gleicheniaceae and the phanerophyte with two species of Cyatheaceae. Hemicryptophytes are more frequent in several Brazilian and worldwide ecosystems (Barudanović et al. 2019; Guislon et al., 2016; Ukaj et al. 2019). The prevalence of hemicryptophytes may be related to the fact that they present the perennial seed at ground level or slightly below it. This characteristic provides protection to vegetative buds against desiccation, while species with less protected buds are subject to greater environmental stress. This is an ecological aspect of the species of this group that occur in Brazil, since numerous studies carried out in different regions of the country have cited hemicryptophytes as being the dominant biological form among species of pteridophytes (Mota et al. 2018; Cordeiro and Neri 2019; Bagheri et al. 2020).

Most species of pteridophytes have high ecological plasticity and the ability to adapt to hostile environments. Some of the registered species have the ability to adapt to more than one type of environment, such as, for example, Anemia phyllitidis, whose preferential environment is the interior and edge of the forest, in addition to the ravine (Mickel 2016). Although it is widely distributed in tropical regions, A. phyllitidis occurred in only area A23, where signs of recovery were observed, being located at the edges and interior of spontaneous vegetation; the species is an herbaceous with terrestrial habit and preference for shaded (scyophyte) and humidity environments, this being the scenario found in the collection area. Telmatoblechnum serrulatum and Neoblechnum brasiliense occur at the edge and interior of the forest and open area, Nephrolepis cordifolia, Macrothelypteris torresiana and Christella dentata in the interior and edge of the forest, Pteridium esculentum in open and clearing, Dicranopteris flexuosa, Gleichenella pustinata and Lygodium venus and gully and Pityrogramma calomelanos in clearing, humid and open place (Pena et al. 2019).

Rumohra antecediformis, despite having the sciophyte form as an environmental adaptation, is common in altered environments, such as the ones in the present study, being able to develop in places with constant solar incidence and varied water supply. Lygodium venustum, adapted to humid environments, mesophilic form, was found in numerous collection areas, having as a common characteristic the substrate formed by pyrite and visibly humid tailings (Bauret et al. 2017).

As for exotic species, only Macrothelypteris torresiana was found in the study areas. This species is naturalized in the neotropics and was introduced from the tropical and subtropical regions of Africa, Asia and the Pacific Islands. It is common in altered humid places, and can form a spore bank (Pena et al. 2019). 
In relation to environmental adaptations, the most representative species were heliophytes, encompassing five families and seven species, followed by two families with one species each that contemplate two forms of adaptations: mesophyll and heliophyte. The locations where they were found contained pure pyrite and tailings mixed with rocks covering the coal layer, with sparse undergrowth, constant sunlight and little humidity, demonstrating the potential that pteridophytes have to survive inhospitable environments.

The species of Blechnaceae (Telmatoblechnum serrulatum and Neoblechnum brasiliense) and Dryopteridaceae (Elaphoglossum sp.) And Dicksoniaceae (Lophosoria quadripinnata) fall under the mesophyte and scyophyte classification and Rumohra antecediformis, also belonging to the Dryopteridaceae family. These plants need shady and humid environments to survive, which denotes the relevance of this group in the actions after the recovery process of areas degraded by coal mining. They were found, preferably, in older landfills, some with recovery attempts, where the substrate was formed by tailings, solum and cover rocks of the coal layer and with other pioneer and secondary plant species of angiosperms, observing that in some places also had exotic trees.

\subsection{Species of ferns and lycophytes and their adaptation to environments}

Figure 2 shows a multivariate analysis of the presence of fern and lycophyte species in the study areas. Areas AT3, A21, A20, A11, A10, A9, A1 and A4 landed only two species belonging to this group.

Area 19 has been used for mining for 42 years and is characterized as open pit mining with the presence of waste. This area presented the greatest diversity of species, which may be related to the absence of $\mathrm{Cd}$ and $\mathrm{Pb}$ concentrations lower than the values established by brazilian legislation.

Pteridium esculentum and Pityrogramma calomelanos were found in the four areas with the highest concentration of Pb (A7, A9, A2 and A18). Neoblechnum brasiliense was found in A2, Telmatoblechnum serrulatum in A7 and Dicranopteris flexuosa in A18. This wide distribution in the sampled areas, mainly of the aforementioned species, is probably related to the fact that many pteridophytes are normally found in a variety of environments with greater anthropic activity (Lehn et al. 2020; López et al. 2020). Telmatoblechnum serrulatum occurs in area A7 (349.1 mg kg-1 of Pb), but no scientific studies have been found on the accumulation of heavy metals for this species. However, accumulation of As has been reported to Blechnum orientale L. by Wang et al. (2007).

Pteridium esculentum was found in 22 areas and Pityrogramma calomelanos in 21 of the 23 areas. Most of these areas are characterized by being landfills of raw tailings, that is, with no recovery process applied yet, unlike the areas where there was no occurrence of these species, which, visually, had signs of recovery, as they presented soil mixed with the tailings and grasses. of varied species. They are the species that occur in area $\mathrm{A} 7\left(349.1 \mathrm{mg} \mathrm{kg}{ }^{-1}\right.$ of $\mathrm{Pb}$ and 08 $\mathrm{mg} \mathrm{kg}^{-1}$ of $\mathrm{Cd}$ ) that presented Pb levels (Table 2) higher than those established by CONAMA Resolution 420/2009. P. calomelanos was observed growing in exposed tailings and with an advanced oxidation stage or when it was mixed with the soil, in more humid places and/or with accentuated solar incidence, close to stones or other plants, in some exposed gullies and clearings direct sunlight. P. calomelanos was used in a study for phytoremediation in mining areas and showed a high capacity to phytostabilize copper in the root and arsenic in its aerial part (Ancheta et al. 2020). Pteridium esculentum showed high capacity to accumulate $U$ and Th in a study conducted in Minas Gerais (Moura et al. 2017). As they were found in areas with high concentrations of Pb, these species ( $P$. esculentum, $P$. calomelanos and $T$. serrulatum) may present phytoextraction or phytostabilization capacity of heavy metals and be used in phytoremediation processes.

As mentioned above, Pteridium esculentum and Pityrogramma calomelanos were found in almost all areas, except in areas A23, AT1 and AT3 for both species, in AT4 P. esculentum and A3 for $P$. calomelanos. Point A23 has eight different species, the highest pH value and a high availability of phosphorus. This area has a small layer of soil covering the tailings. It is worth mentioning that the amount of phosphorus can interfere in the variety and adaptation of plant species (Copete et al. 2019).

Preferably, ferns and lycophytes occur in environments with regular water support and shading, however some of them are able to survive in dry environments with constant sunlight. For this, they developed a series of environmental adaptations such as, for example, protection against fire, water deficit, among others, allowing their development in hostile environments (Campos et al. 2018). However, caution is needed when using plants from contaminated areas due to bioaccumulation, as some species are used by humans for consumption, such as Blechnum orientale, which is used in the form of tea for medicinal purposes, which can cause contamination by metals ( $\mathrm{Cu}, \mathrm{Zn}, \mathrm{Mn}, \mathrm{Pb}, \mathrm{Cd}, \mathrm{Cr}$, As and $\mathrm{Hg}$ ) and by polyaromatic hydrocarbons (HPA) (Yu et al. 2020).

\section{Conclusion}

In the survey of ferns and lycophytes carried out in places of tailings and waste landfills in mining areas, in the southern Santa Catarina state, 17 species belonging to 11 botanical families were registered. This data showed the capacity of fern and lycophyte species to develop in extremely degraded environments, raising the possibility that species of this group of plants can be used in the initial stages in environmental recovery programs.

The presence of the species Pteridium esculentum, Pityrogramma calomelanos and Telmatoblechnum serrulatum in areas with high concentrations of Pb, indicates that these species may have potential for phytoextraction and phytostabilization of heavy metals.

\section{Declarations}

\section{ACKNOWLEDGMENTS}

To Roseli Bortoluzzi, to the University of the Extreme South of Santa Catarina (UNESC) and the Federal Public Ministry of Santa Catarina (MPF-SC).

\section{Ethical Approval}


Not applicable.

\section{Consent to Participate}

Not applicable.

\section{Consent to Publish}

All authors have consent to publish this article.

\section{Authors Contributions}

All authors contributed to this research. The article this is based on the Andreola A's thesis. Material preparation, collection and analysis of the data were performed by Andreola A, Biasi JP, Campos ML and Rosini DN. Zanette VC, Bortoluzzi RLC and Nicoleite ER worked on collecting, identifying and specimens of plant species. Miquelutti DJ worked on statistical analysis. All authors writed the article, commented on previous versions of the manuscript and all authors read and approved the final manuscript.

\section{Funding}

CAPES for the availability of the scholarship to carry out the work.

\section{Competing Interests}

The authors declare that they have no competing interests.

\section{Availability of data and materials}

Not applicable.

\section{References}

AKOPYAN, K. et al. Assessment of residential soil contamination with arsenic and lead in mining and smelting towns of northern Armenia. Joumal of Geochemical Exploration, v. 184, p. 97-109, 1 jan. 2018.

ALTHAUS, D. et al. Natural fertility and metals contents in soils of rio grande do sul (Brazil). Revista Brasileira de Ciencia do Solo, v. 42, p. 1-15, 2018.

ANCHETA, M. H. et al. Copper and arsenic accumulation of Pityrogrammacalomelanos, Nephrolepis biserrata, and Cynodon dactylon in Cu- And Au- mine tailings. Joumal of Degraded and Mining Lands Management, v. 7, n. 3, p. 2201-2208, 2020.

BAGHERI, S. et al. Relationship between broadleaved mixed forest understory species groups with soil and elevation in a semi-arid Persian oak (Quercus brantii L.) ecosystem. Caspian Journal of Environmental Sciences, v. 18, n. 2, p. 157-170, 2020.

BARUDANOVIĆ, S. et al. State of peatland ecosystems in Bosnia and Herzegovina. Fondeco Science, v. 1, n. 1, p. 48-60, 2019.

BAURET, L. et al. Molecular data, based on an exhaustive species sampling of the fern genus Rumohra (Dryopteridaceae), reveal a biogeographical history mostly shaped by dispersal and several cryptic species in the widely distributed Rumohra adiantiformis. Botanical Journal of the Linnean Society, v. 185, n. 4 , p. $463-481,1$ nov. 2017.

BENAVENTE, D. et al. Remediation by waste marble powder and lime of jarosite-rich sediments from Portman Bay (Spain). Environmental Pollution, v. 264, p. 114786, 1 set. 2020 .

BILIBIO, C. et al. Drainage properties of technosols made of municipal solid waste incineration bottom ash and coal combustion residues on potash-tailings piles: A lysimeter study. Journal of Cleaner Production, v. 279, p. 123442, 10 ago. 2021.

BOUKEMARA, L. et al. Characterization of phosphorus interaction with sediments affected by acid mine drainage - relation with the sediment composition. International Journal of Sediment Research, v. 32, n. 4, p. 481-486, 1 dez. 2017.

BRASIL. CONAMA Resolution 420 Dezember $28^{\text {st }} 2009$ which provides for criteria and guiding values of soil quality regarding the presence of chemical substances and establishes guidelines for the environmental management of areas contaminated by these substances. Brazil, DF, 2009: [s.n.].

CAMPOS, M. L. et al. Impacts on soil caused by mining and landfill of coal tailings | Campos | Revista de Ciências Agroveterinárias. Journal of Agroveterinary Sciences, v. 9, n. 2, 2010.

CAMPOS, M. L.; ALMEIDA, J. A.; SOUZA, L. S. Evaluation of three areas of soil built after open pit coal mining in Lauro Müller, Santa Catarina. Revista Brasileira de Ciência do Solo, v. 27, n. 6, p. 1123-1137, dez. 2003.

CAMPOS, P. V. et al. Plant diversity and community structure of Brazilian Páramos. Journal of Mountain Science, v. 15, n. 6, p. 1186-1198, 1 jun. 2018. 
CHEN, Y. Y. et al. The relationship between lead and cadmium levels and functional dependence among elderly participants. Environmental Science and Pollution Research, v. 27, n. 6, p. 5932-5940, 1 fev. 2020.

COPETE, J. C. et al. Relationship between floristic composition and soil nutrients in palm communities at the chocó region of Colombia and Ecuador. Revista de Biologia Tropical, v. 67, n. 4, p. 716-732, 1 set. 2019.

CUNHA, M. P. et al. Long-term performance of a UASB reactor treating acid mine drainage: effects of sulfate loading rate, hydraulic retention time, and COD/SO 42- ratio. Biodegradation, v. 30, n. 1, p. 47-58, 15 fev. 2019.

CUTRUNEO, C. M. N. L. et al. A mineralogical and geochemical study of three Brazilian coal cleaning rejects: Demonstration of electron beam applications. International Journal of Coal Geology, v. 130, p. 33-52, 15 ago. 2014.

DAY, P. Methods of Soil Analysis 2d ed., pt. 1; Physical and Mineralogical Methods. Soil Science, v. 146, n. 2, p. $138,1965$.

DUARTE, A. L. et al. Hazardous elements and amorphous nanoparticles in historical estuary coal mining area. Geoscience Frontiers, v. 10, n. 3, p. 927-939, 1 maio 2019 .

DUTTA, M. et al. Acid mine drainage in an Indian high-sulfur coal mining area: Cytotoxicity assay and remediation study. Journal of Hazardous Materials, v. 389, p. 121851, 5 maio 2020.

EMBRAPA. Manual of soil analysis methods. infoteca.cnptia.embrapa.br, 1997.

ESLAVA-SILVA, F. D. J. et al. Morfo-anatomía del ciclo de vida del helecho Pteridium aquilinum (Dennstaedtiaceae) en cultivo in vitro. Revista de Biología Tropical, v. 68, n. 1, p. 12-22, 2019.

FILGUEIRAS, T. S. et al. Walking: an expeditious method for qualitative floristic surveys. Cadernos de Geociências, v. 12, n. 4, p. 39-43, 1994.

Flora do Brasil 2020 em construção. Rio de Janeiro Botanical Garden. Disponível em: < http://floradobrasil.jbrj.gov.br/ >. Acesso em: 15 nov. 2020

FLORES, B. D. Study of the thermoplastic behavior of coal from the Barro Branco layer (Santa Catarina - Brazil) and its influence on the coking process. [s.I.] Universidade Federal do Rio Grande do Sul. , 2018.

GANKHUREL, B. et al. Comparison of Chemical Speciation of Lead, Arsenic, and Cadmium in Contaminated Soils from a Historical Mining Site: Implications for Different Mobilities of Heavy Metals. ACS Earth and Space Chemistry, v. 4, n. 7, p. 1064-1077, 16 jul. 2020.

\section{GASPER, A.; SEVEGNANI, L. Lycophyta e samambaias do Parque Nacional da Serra do Itajaí, Vale do Itajaí, SC, Brasil. Hoehnea, v.37, n.4, 2010}

GEE, G.; BAUDER, J. Part 1-Physical and Mineralogical Methods. Methods of Soil Analysis, ASA, Madison, 1986.

GRANT, L. D. LEAD AND COMPOUNDS. In: Environmental Toxicants. [s.I.] Wiley, 2020. p. 627-675.

GUISLON, A. V. et al. Structure of herbaceous vegetation in riparian landscapes in southern Santa Catarina, Brazil. Revista Ambiente e Agua, v. 11, n. 3, p. 650$664,2016$.

HARA, A. et al. Incidence of nephrolithiasis in relation to environmental exposure to lead and cadmium in a population study. Environmental Research, v. 145, p. 1-8, 1 fev. 2016 .

HEOELZEL, M. C.; MIZUSAKI, A. M. P. Aquifer interconnectivity and the effects of acid mine drainage on the water quality of the Santa Catarina Carboniferous Basin (SC)). Santa Maria: Universidade Federal do Rio Grande do Sul, 2018.

INDA, A. V. et al. Chemical attributes of constructed soils after surface coal mining related to sulphurization process. Ciencia Rural, v. 40, n. 5, p. 1060-1067, 2010.

KACHINSKI, W. D.; VIDIGAL, J. C. B.; ÁVILA, F. W. Zinco no solo, na planta e a saúde humana: uma revisão. Research, Society and Development, v. 9, n. 7, p. e827973544, 16 jun. 2020.

KEFENI, K. K.; MSAGATI, T. A. M.; MAMBA, B. B. Acid mine drainage: Prevention, treatment options, and resource recovery: A reviewJoumal of Cleaner ProductionElsevier Ltd, , 10 maio 2017.

KIRK NORDSTROM, D. Geochemical Modeling of Iron and Aluminum Precipitation during Mixing and Neutralization of Acid Mine Drainage. Minerals, v. 10, n. 6, p. 547,17 jun. 2020.

KUBITZKI, K. The families and genera of vascular plants. Flowering Plants. Eudicots: Malpighiales, v. 11, p. 1-332, 2014.

LEHN, C. R.; GONZATTI, F.; ARANA, M. D. Ferns and lycophytes from the Cerro do Tigre and Cerro Palomas, Pampa biogeographic province, Rio Grande do Sul State, Brazil. Biological Sciences, 2020. 
LÓPEZ, S. et al. Landscape change in Southern Ecuador: An indicator-based and multi-temporal evaluation of land use and land cover in a mixed-use protected area. Ecological Indicators, v. 115, p. 106357, 1 ago. 2020.

MARQUES, M.; MARQUES, M. M.; KRUPEK, R. A. Epiphytic ferns on Dicksonia sellowiana Hook caudices. (Dicksoniaceae) and Cyathea phalerata Mart. (Cyatheaceae) in a remnant of mixed ombrophilous forest in the municipality of Porto União, SC, southern Brazil. AMBIÊNCIA, v. 14, n. 3, p. 549-560, 11 abr. 2019.

MICKEL, J. M. Anemia (Anemiaceae), Flora Neotropica Monograph. New York: The New York Botanical, 2016. v. 118

MILIOLI, G.; SANTOS, R. DOS; CITADINI-ZANETTE, V. Coal mining, the environment and sustainable development in southern Santa Catarina: an interdisciplinary approach. 2009.

MIRELES, I. et al. Kinetic analysis of the decomposition of the KFe3 (SO4 )2-x (CrO4 )x (OH)6 jarosite solid solution in $\mathrm{Ca}(\mathrm{OH}) 2 \mathrm{medium}$. Journal of the Brazilian Chemical Society, v. 27, n. 6, p. 1014-1025, 1 jun. 2016.

MOTA, G. S. et al. Changes in species composition, vegetation structure, and life forms along an altitudinal gradient of rupestrian grasslands in south-eastern Brazil. Flora: Morphology, Distribution, Functional Ecology of Plants, v. 238, p. 32-42, 1 jan. 2018.

MOURA, R. R. DE; MENEZES, M. Â. DE B. C.; MARQUES, D. J. Evaluation of the concentrations of rare earth elements, uranium and thorium in the soil-plant system by Neutron Activation. International Nuclear Atlantic Conference, 2017.

MUSILOVA, J. et al. Environmental Contamination by Heavy Metals in Region with Previous Mining Activity. Bulletin of Environmental Contamination and Toxicology, v. 97, n. 4, p. 569-575, 1 out. 2016.

OLIVEIRA, C. M. et al. Valorization of iron pyrite from coal mining in southern Brazil. Joumal of Environmental Chemical Engineering, v. 7, n. 1, p. 102931, 1 fev. 2019.

OLIVEIRA, S. A. DE; TAVARES, S. R. DE L.; BARBOSA, M. C. Pb Adsorption on Soil Typical to an Ammunition Destruction Site. Bulletin of Environmental Contamination and Toxicology, v. 101, n. 3, p. 365-371, 1 set. 2018.

PELLETIER, N. et al. Lead contamination from gold mining in Yellowknife Bay (Northwest Territories), reconstructed using stable lead isotopes. Environmental Pollution, v. 259, p. 113888, 1 abr. 2020.

PENA, N. T. L. et al. Original article/original paper ferns and lycophytes from elephant stone, Espírito Santo, Brazil.. Rodriguesia, v. $70,2019$.

PPG-I (Pteridophyte Phylogeny Group). A community-derived classification for extant lycophytes and ferns. Journal of Sytematics and Evolution v.54, p. 563$603,2016$.

PRABHU, S. et al. Characterization of gamma ray induced variations in plant systems View project Studies on the potential of Pteris vittata L. as a biosorbent for removal of heavy metals View project. IJRET: International Journal of Research in Engineering and Technology, p. 2321-7308, 2016.

PRAVEEN, A.; PANDEY, V. C. Pteridophytes in phytoremediation. Environmental Geochemistry and Health, v. 42, n. 8, p. 2399-2411, 2020.

R CORE TEAM. The R Project for Statistical Computing, 2013. Found in: <https://www.r-project.org/>. Acesso em: 14 set. 2020

ROTHFELS, C. J. et al. A revised family-level classification for eupolypod II ferns (Polypodiidae: Polypodiales). TAXON, v. 61, n. 3, p. 515-533, 1 jun. 2012.

RUCANDIO, I.; PETIT, D. Determination of cadmium in coal fly ash, soil and sediment samples by GFAAS with evaluation of different matrix modifiers.

Fresenius' Journal of Analytical Chemistry, v. 364, n. 6, p. 541-548, 1999.

RUPPENTHAL, M. Toxicologia. Santa Maria: Rede Etec Brasil, 2013. v. 128

SILVA, L. F. O.; WOLLENSCHLAGER, M.; OLIVEIRA, M. L. S. A preliminary study of coal mining drainage and environmental health in the Santa Catarina region, Brazil. Environmental Geochemistry and Health, v. 33, n. 1, p. 55-65, 18 fev. 2011.

SOMANI, M. et al. Contaminants in soil-like material recovered by landfill mining from five old dumps in India. Process Safety and Environmental Protection, v. 137, p. 82-92, 1 maio 2020 .

SOUZA JUNIOR, T. F.; MOREIRA, E. B.; HEINECK, K. S. Mining tailings dams in Brazil. HOLOS, v. 34, 2018.

STAUB, C. P. P. Adsorption Of Pb 2+ By Hematite and Goethite Nanoparticles Recovered. [s.I.] Universidade Tecnológica Federal do Paraná, 13 set. 2019.

TABELIN, C. B. et al. Solid-phase partitioning and release-retention mechanisms of copper, lead, zinc and arsenic in soils impacted by artisanal and small-scale gold mining (ASGM) activities. Chemosphere, v. 260, p. 127574, 1 dez. 2020.

TEDESCO, M. et al. Analysis of soil, plants and other materials. In: Porto Alegre: [s.n.].

UKAJ, S.; RIZANI, H.; RIZANI, S. SOME PLANTS FROM THE LAMIACEAE FAMILY TO KREU I AHISHTËS - KOSOVO. UBT International Conference, 2019. 
USEPA. Method 3051A: Microwave assisted acid digestion of sediments, sludges, soils, and oils. USEPA, n. February, p. 1-30, 2007.

WALKLEY, A.; BLACK, I. An examination of the Degtjareff method for determining soil organic matter, and a proposed modification of the chromic acid titration method. Soil science, v. 37, n. 1, p. 29-38, 1934.

WANG, H. B. et al. Uptake and accumulation of arsenic by 11 Pteris taxa from southern China. Environmental Pollution, v. 145, n. 1, p. $225-233,1$ jan. 2007.

YU, H. et al. Accumulation of Heavy Metals and As in the Fern Blechnum orientale L. from Guangdong Province, Southern China. Water, Air, and Soil Pollution, v. 231 , n. 7, p. $1-12,1$ jul. 2020.

YUAN, Z. et al. Rapid abiotic As removal from As-rich acid mine drainage: Effect of $\mathrm{pH}, \mathrm{Fe} / \mathrm{As}$ molar ratio, oxygen, temperature, initial As concentration and neutralization reagent. Chemical Engineering Journal, v. 378, p. 122156, 15 dez. 2019.

\section{Figures}
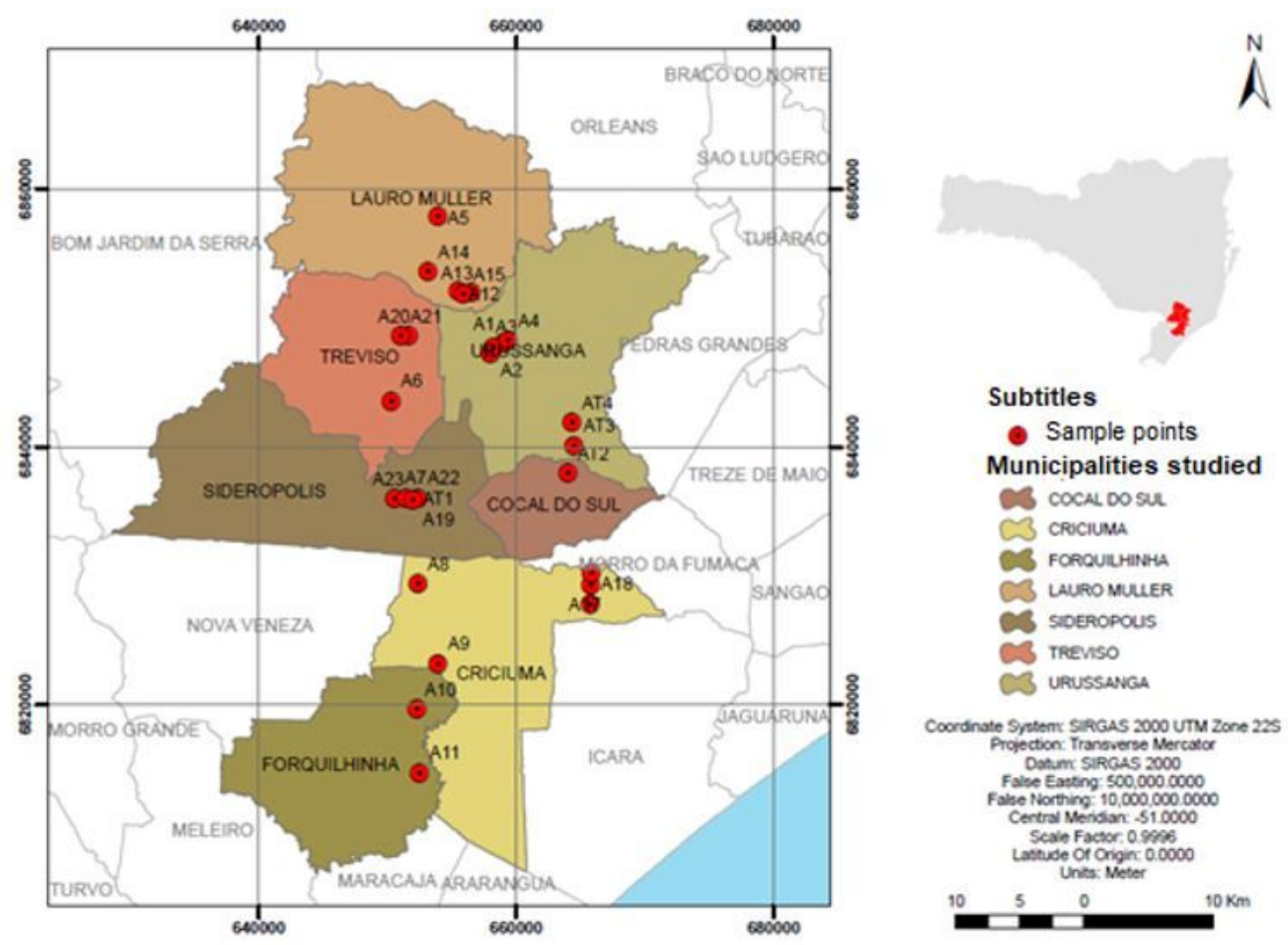

Figure 1

Location of coal mining tailings landfills in southern Santa Catarina.

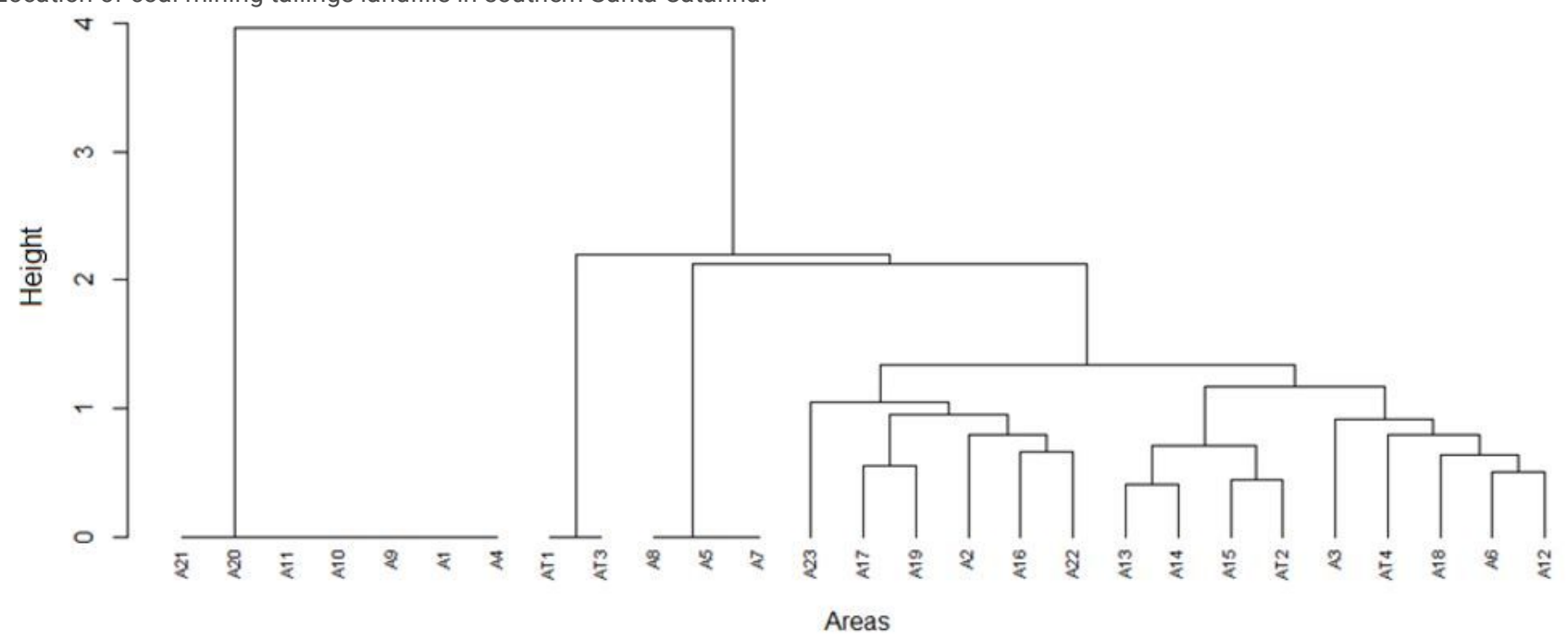

Figure 2

Multivariate distance between areas based on the presence or absence of fern and lycophyte species from the Jaccard index calculation. 